\title{
ARAHAN TATA HUBUNGAN KELEMBAGAAN KESATUAN PENGELOLAAN HUTAN (KPH) DI INDONESIA
}

\author{
AHMAD MARYUDI \\ Departemen Manajemen Hutan, Fakultas Kehutanan, Universitas Gadjah Mada \\ Jl. Agro No. 1 Bulaksumur, Sleman 55281 \\ Email:maryudi76@yahoo.com
}

\begin{abstract}
The establishment of Forest Management Units (FMUs) has been made as one of the top policy priorities by the Ministry of Environment and Forestry. The policy is expected to become a solution for problems regarding to the management of forests in Indonesia, e.g. poor forest governance, tenurial problems, limited capacity in the management of forests. FMU is conceptualized as a forest management agent/ institution at the field. The policy of establishing FMUs is often viewed to add complexities of the current forest administration and management structures. This paper discusses concepts of institutions and bureaucracies of the FMU policy.
\end{abstract}

Keywords: Forest Management Units (FMUs), administration, bureaucracies, authority, recentralization.

\section{INTISARI}

Pembentukan Kesatuan Pengelolaan Hutan (KPH) menjadi salah satu prioritas kebijakan Kementerian Lingkungan Hidup dan Kehutanan. Kebijakan ini diharapkan dapat menjadi solusi bagi berbagai permasalahan mendasar pengelolaan hutan di Indonesia, seperti tata kelola yang buruk, ketidakjelasan hak tenurial, dan lemahnya kapasitas dalam manajemen hutan. KPH dikonseptualisasikan sebagai penyelenggara pengelolaan hutan di tingkat tapak. Kebijakan pembangunan KPH yang diatur oleh pusat dipandang dapat menambah kompleksitas terhadap struktur pengurusan dan pengelolaan yang sudah ada selama ini.Makalah ini membahas konsep tata hubungan kelembagaan dalam kebijakan KPH.

Kata kunci: KPH, pengurusan, kelembagaan, kewenangan, resentralisasi. 


\section{PENDAHULUAN}

Undang-Undang Dasar 1945 dan UndangUndang Kehutanan No. 41/ 1999 mengamanatkan pengelolaan sumberdaya hutan yang sebaik-baiknya secara berkelanjutan agar hutan dapat memberi kemanfaatan yang optimal bagi bangsa dan negara. Sayangnya, pengurusan dan pengelolaan sumberdaya hutan di Indonesia belum menggembirakan, yang dicerminkan oleh deforestasi dan degradasi hutan yang terus berlangsung. Sampai dengan pertengahan dekade 1980-an, diperkirakan lebih dari 20 juta hektar hutan Indonesia rusak parah (Hurst, 1990). Angka deforestasi meningkat tajam dari 300 ribu hektar/ tahun pada dekade 1970-an menjadi satu juta hektar/tahun pada awal 1990-an (World Bank, 1990). Angka deforestasi mencapai puncaknya pada akhir dekade 1990-an yaitu hampir tiga juta hektar/ tahun. Walaupun data resmi pemerintah menunjukkan penurunan yang cukup nyata dalam beberapa tahun terakhir (Kementerian Kehutanan, 2012), deforestasi di Indonesia relatif masih cukup akut. Studi terbaru dari Hansen et al. (2013) menunjukkan bahwa angka deforestasi di Indonesia tercatat sebesar dua juta hektar/ tahun dari tahun 2011 sampai dengan 2012.

Belum optimalnya kebijakan di sektor kehutanan tersebut disinyalir (salah satunya) disebabkan oleh kebijakan pemerintah di masa lalu, yang hanya melaksanakan fungsi administrasi pengurusan hutan dan belum melaksanakan pengelolaan hutan secara fungsional sehingga sebagian besar kawasan hutan yang ditetapkan tidak memiliki kelembagaan pengelola pada tingkat tapak (Kartodihardjo et al., 2011). Oleh karena itu, pemerintah c.q. Kementerian Lingkungan Hidup dan Kehutanan (KLHK) menetapkan prioritas kebijakan pembentukan/ pembangunan Kesatuan Pengelolaan Hutan (KPH) sebagaimana yang tertuang dalam UU No 41 tahun
1999 yang dijabarkan pada PP Nomor 6 Tahun 2007 Jo. PP Nomor 3 Tahun 2008.

Pembangunan KPH ditujukan untuk menjawab kebutuhan akan perlunya unit pengelolaan hutan di tingkat tapak dan organisasi pengelolanya untuk mencapai kelestarian (Kartodihardjo et al., 2011). Dengan adanya KPH diharapkan mampu menjadi pengelola di tingkat tapak untuk mencapai terwujudnya pengelolaan hutan yang berkelanjutan. Kebijakan KPH diharapkan berfungsi sebagai enabling condition terhadap upaya memperbaiki tata-kelola hutan, memperlambat laju degradasi, mempercepat rehabilitasi hutan dan lahan, pelaksanaan perlindungan dan pengamanan hutan, pelaksanaan optimalisasi pemanfaatan hutan, meningkatkan stabilitas pasokan hasil hutan, dan menyediakan data dan informasi kawasan hutan. Secara umum, sasaran yang ingin dicapai dengan kebijakan pembentukan KPH ini adalah memberikan kepastian: 1) areal kerja pengelolaan hutan, 2) wilayah tanggung jawab pengelolaan, dan 3) satuan perencanaan pembangunan dan pengelolaan hutan, yang kesemuanya merupakan prasyarat kunci bagi pengelolaan hutan lestari (Departemen Kehutanan, 2006).

Permulaan pembentukan KPH sebenarnya sudah dimulai sejak ditetapkannya kebijakan Pemerintah berupa UU Nomor 5 Tahun 1967 tentang KetentuanKetentuan Pokok Kehutanan. Namun amanat pembentukan KPH secara jelas baru tertuang dalam UU Nomor 41 tahun 1999 tentang Kehutanan, yang ditindaklanjuti dengan Peraturan Pemerintah Nomor 44 Tahun 2004 Tentang Perencanaan Kehutanan, dan Peraturan Pemerintah Nomor 6 Tahun 2007 yang telah diubah dengan Peraturan Pemerintah Nomor 3 Tahun 2008 tentang Tentang Tata Hutan dan Penyusunan Rencana Pengelolaan Hutan Serta Pemanfaatan Hutan. Kebijakan pembentukan KPH 
ini ditujukan untuk menyediakan wadah bagi terselenggaranya kegiatan pengelolaan hutan secara efisien dan lestari (Badan Planologi, 2006). KPH merupakan konsep kewilayahan pengelolaan hutan sesuai dengan fungsi pokok dan peruntukannya, yang dapat dikelola secara efisien dan lestari. Direncanakan seluruh kawasan hutan di Indonesia akan dibagi-bagi dalam wilayah KPH.

Pembangunan KPH menghadapi beberapa tantangan terutama berkaitan dengan kebijakan otonomi daerah kewenangan bidang kehutanan, khususnya pengelolaan hutan lindung dan hutan produksi yang berada di bawah Dinas Kehutanan daerah. Di awal munculnya konsep KPH yang merupakan ide pemerintah pusat, memunculkan banyak perdebatan berbagai kalangan tentang bagaimana hubungannya dengan lembaga lain yang sudah ada. Sebagian pihak menuding bahwa KPH merupakan upaya pemerintah pusat untuk mengambil alih kembali kuasa pengurusan hutan di era otonomi daerah sekarang ini. Kebijakan pembangunan $\mathrm{KPH}$ yang diatur oleh pusat dipandang dapat menambah kompleksitas terhadap struktur pengurusan dan pengelolaan yang sudah ada selama ini (Kim et al., 2015). Hal ini diperkuat dengan adanya UU. 23/2014 yang secara nyata menunjukkan upaya resentralisasi tersebut. Makalah ini membahas konsep tata hubungan kelembagaan dalam kebijakan $\mathrm{KPH}$.

\section{KERANGKA TEORI: PEMISAHAN PENGURUSAN DAN PENGELOLAAN HUTAN}

Arahan pengembangan kelembagaan KPH harus mengedepankan kejelasan peran, fungsi koordinasi, dan sinergisitas peran berbagai pihak berdasarkan tata hubungan kerja, hak, dan kewenangan masing-masing untuk mendorong sistem keprana- taan pengelolaan hutan yang baik (good forest governance). Tumpang tindih peran dan kewenangan diantara berbagai institusi/ lembaga terkait seringkali menjadi akar dari carut marut pengelolaan hutan di Indonesia (lihat: McCarthy, 2000; Brockhaus et al., 2012; Maryudi, 2015). Oleh karena itu, tata kelembagaan KPH harus memberikan gambaran tugas dan fungsi yang jelas dari masing-masing institusi, sehingga dapat menghindarkan tumpang tindih peran dan kewenangan. Kelembagaan sering diasosiasikan sebagai batasan-batasan yang dibuat dalam sebuah arena politik untuk membentuk pola interaksi sosial dan politik antar individu/lembaga, yang secara gamblang mendefinisikan dan menentukan aturan dan prosedur dalam bertindak (North, 1990; Ostrom 1999). Oleh karena itu, kelembagan harus diterjemahkan dalam aturan main yang disepakati sebagai sesuatu yang harus diikuti dan dipatuhi (memiliki kekuatan sanksi) dengan tujuan terciptanya keteraturan dan kepastian interaksi sosial.

Kelembagaan KPH sangat berkaitan erat dengan struktur birokrasi yang melingkupinya. Struktur birokrasi secara umum mengacu kepada institusiinstitusi publik seperti kementerian dan badan-badan tertentu yang mempunyai kewenangan untuk mengambil keputusan yang didasarkan pada standar legal dan formal (Giessen et al., 2014). Struktur birokrasi tidak hanya berada dalam satu aras saja, namun mencakup berbagai lembaga di berbagai level dari pusat sampai dengan lokal (Krott et al., 2014). Dalam satu isu atau permasalahan tertentu, keputusan politik merupakan hasil dari negosiasi dan tawar menawar diantara struktur birokrasi yang saling bersaing (Peters dan Pierre, 2007; Giessen dan Krott, 2009; Hubo dan Krott, 2013). Birokrasi secara formal menjalankan kepentingan publik sesuai dengan mandat yang diberikan (Niskanen, 1971; Krott, 1990). Namun dalam sebuah struktur 
birokrasi, sering terjadi persaingan antara satu lembaga/badan dengan yang lainnya untuk mendapatkan sumberdaya, domain, dan pengaruh politik (Hubo dan Krott, 2010).

Oleh karena itu, di dalam suatu struktur birokrasi harus ada arahan yang jelas, yang meminimalkan peluang munculnya konflik mandat dan kewenangan yang dapat mendorong persaingan antar lembaga untuk memperjuangkan kepentingannya sendiri. Dalam beberapa dekade terakhir muncul gerakan “New Public Management" (NPM) yang mendorong reforma birokrasi dengan memisahkan fungsi pengurusan (administration) dan pengelolaan (management). Inti dari gerakan tersebut adalah adopsi ekonomi pasar sebagai filosofi hubungan antara politik dan administrasi (Nagel, 1997). NPM bertujuan mendorong efisiensi dalam layanan publik yang selama ini dianggap kurang tanggap terhadap aspirasi publik (Nagel, 1997). Gerakan ini tidak lepas dari pandangan skeptis atas kapasitas birokrasi dalam menjalankan kepentingan publik. Richardson dan Jordan (1979) dikutip Marinetto (2003) dengan apik menggambarkan kondisi ini sebagai "negara kelebihan muatan", dimana negara dipersepsikan sebagai sebuah institusi yang inefisien dan menanggung beban anggaran yang sangat tinggi (Ruhanen et al., 2010).

Pembagian peran dan wewenang merupakan salah satu kunci untuk menyelesaikan problematika tersebut. Light (1997) menyatakan bahwa harus ada pemisahan yang jelas antara fungsi administrasipengambilan kebijakan (policy making) dan fungsi pengelolaan-pemberian layanan (service delivery). Filosofi pemisahan ini adalah untuk menghindari konflik mandat dan tanggung jawab (Terry, 2005). Oleh karena itu, keberadaan unit pengelolaan harusnya diperuntukkan untuk menterjemahkan misi-misi yang ditetapkan oleh unit pengurusan/ administrasi, dan unit pengurusan harus diperankan untuk mendukung unit pengelolaan dalam menggapai misi yang ditetapkan.

\section{KONTEKS}

Kebijakan pembangunan KPH saat ini dilingkupi semangat resentralisasi yang dilakukan pemerintah pusat yang dimulai semenjak tahun 2004 dengan dikeluarkannya UU No. 23/2004 menggantikan regulasi desentralisasi UU No. 22/1999. Hadirnya UU 23/2004 mulai merekonstruksi keseimbangan antara kewenangan pusat dan daerah (Maryudi, 2015). UU No. 23/2014 dianggap sebagai penyempurnaan proses resentralisasi tersebut (Sahide et al.., 2016a,b; HUMA, 2016). UU 23/2014 memberikan dasar penarikan kewenangan sektor kehutanan ke tingkat provinsi. Arahan tata hubungan kelembagaan $\mathrm{KPH}$ disini harus dipandang dalam konteks resentralisasi tersebut.

Tulisan ini disusun berdasarkan premis perlunya pemisahan fungsi pengurusan/administrasi dan pengelolaan hutan (Tabel 1). Fungsi administrasi merupakan semua hal yang berkenaan dengan proses-proses pengambilan kebijakan serta penyusunan prinsip, norma, dan peraturan (Krott, 2005), sedangkan fungsi pengelolaan mencakup serangkaian aktivitas yang berkenaan pelaksanaan kegiatan kehutanan di lapangan untuk mencapai tujuan yang telah ditetapkan oleh pengampu fungsi administrasi. Dalam konteks resentralisasi (penarikan kewenangan) ke tingkat propinsi, arahan untuk fungsi pengurusan/administrasi harus diperankan oleh pemerintah propinsi (Dinas Kehutanan Propinsi), sedangkan KPH harus diposisikan semata untuk mengampu fungsi pengelolaan (service delivery). 
Tabel 1. Fungsi Pengurusan dan Pengelolaan Hutan

\begin{tabular}{|c|c|c|}
\hline Cakupan & Pengurusan Hutan & Pengelolaan Hutan \\
\hline $\begin{array}{l}\text { Kaj } \\
\text { teor }\end{array}$ & $\begin{array}{l}\text { - Regulasi prinsip, norma dan peraturan terkait } \\
\text { dengan pengelolaan hutan } \\
\text { - Perencanaan hutan (makro) } \\
\text { - Pemberian ijin } \\
\text { - Regulasi sistem manajemen (isu ketenaga- } \\
\text { kerjaan, tenurial, mekanisme resolusi konflik } \\
\text { dll) }\end{array}$ & $\begin{array}{l}\text { - Perencanaan pengelolaan hutan } \\
\text { - Pemanfaatan hutan } \\
\text { - } \text { Rehabilitasi hutan } \\
\text { - Perlindungan hutan } \\
\text { - Pemanenan hasil hutan } \\
\text { - } \text { Manajemen konflik }\end{array}$ \\
\hline $\begin{array}{l}\text { Kajian } \\
\text { dokumen } \\
\text { legal }\end{array}$ & $\begin{array}{l}\text { - Penunjukan dan pengukuhan kawasan } \\
\text { - Pembentukan wilayah kelola } \\
\text { - Pengesahan rencana pengelolaan dan rencana } \\
\text { - } \text { usaha } \\
\text { - Penerbitan ijin } \\
\text { - Pengaturan penataanusaahaan } \\
\text { - Perimaan negara } \\
\text { - } \text { Pehutanan } \\
\text { - Pengawasan bidang kehutanan } \\
\text { Pengaturan mekanisme pertanggungjawaban }\end{array}$ & $\begin{array}{l}\text { - Inventarisasi hutan, penataan batas dan } \\
\text { - } \quad \text { Perenetaan kawasan } \\
\text { dibentuk (jangka panjang, menengah, pendek) } \\
\text { - Pemanfaatan (pemanenan) hasil hutan dan } \\
\text { kawasan hutan } \\
\text { - } \text { Industri kehutanan } \\
\text { - Rehabilitasi lahan dan kawasan } \\
\text { - Pemberdayaan masyarakat } \\
\text { - Pembangunan sistem informasi sumberdaya } \\
\text { pada kawasan kelola }\end{array}$ \\
\hline
\end{tabular}

\section{ARAHAN TATA HUBUNGAN KELEMBAGAAN}

\section{Hubungan KPH dengan Dinas Kehutanan Propinsi}

Organisasi KPH membawa satu konsekuensi formal bahwa secara struktural hirarki KPH akan bertanggung jawab secara langsung kepada Dinas Kehutanan. Yang menjadi tantangan selanjutnya adalah merumuskan tugas, peran, dan wewenang di antara keduanya sehingga tumpang tindih bisa diminimalkan. Seperti telah disampaikan di muka, Dinas Kehutanan untuk ke depannya dapat didorong untuk mengampu fungsi administrasi, sedangkan $\mathrm{KPH}$ akan mengampu fungsi manajemen/pengelolaan hutan (Tabel 1). Dinas Kehutanan lebih diposisikan sebagai instansi yang menelorkan berbagai kebijakan untuk hutan yang ada di wilayahnya. Sedangkan KPH bertanggung jawab secara penuh atas kegiatan operasional dengan panduan kebijakan-kebijakan yang telah disusun oleh Dinas Kehutanan.
Dalam tataran praktis, KPH akan menjadi lembaga otonom (dalam konteks manajerial hutan), namun akan bertanggungjawab kepada Dinas Kehutanan. Ini membawa implikasi bahwa KPH nantinya akan mempunyai ruang berkreasi yang cukup luas terkait dengan penentuan opsi pengelolaan hutan. KPH menyusun perencanaan jangka panjang untuk keseluruhan kawasan. Rencana ini harus diselaraskan dengan kebijakan dan tujuan pembangunan kehutanan yang telah digariskan oleh pemerintah daerah yang selanjutnya akan disyahkan oleh Gubernur atas rekomendasi Kepala Dinas Kehutanan. Pemerintah Daerah nantinya dapat meminta informasi yang akurat atas luas/volume pemanfaatan yang akan menjadi dasar bagi perhitungan penerimaan pajak dan pendapatan lain, dan sebagainya.

\section{Hubungan KPH dengan IUPHHK}

Dalam konteks pengelolaan/pengusahaan hutan di Indonesia telah ada IUPHHK sebelum 
dibentuknya KPH. Hal ini membuka peluang konflik mandat urusan pengelolaan apabila KPH difungsikan untuk memayungi berbagai ijin. Sebagaimana diatur dalam PP6/2007, IUPHHK-HT merupakan ijin usaha yang diberikan untuk memanfaatkan hasil hutan berupa kayu dan/atau bukan kayu dalam hutan tanaman pada hutan produksi melalui kegiatan penyiapan lahan, pembibitan, penanaman, pemeliharaan, pemanenan, dan pemasaran. Sebelum terbentuknya KPH (versi pemerintah), sebagian IUPHHK yang ada telah melaksanakan kegiatankegiatan yang sebenarnya merupakan fungsi pengelolaan seperti tata hutan, inventarisasi, dan perlindungan di wilayah masing-masing.

Telepas dari berbagai argumentasi bahwa IUPHHK hanya sekedar memfokuskan pada pemanfaatan (dan bukan pengelolaan), sebenarnya IU inilah yang sebenarnya bisa didorong menjadi unit pengelola, bukan KPH versi baru pemerintah. Pembentukan KPH justru akan membentuk semacam “supra manajer" bagi ijin-ijin yang telah ada. Apabila konteks pemayungan ijin-ijin yang telah ada dihubungkan dengan fungsi pengawasan dan monitoring, KPH justru mengambil fungsi pengurusan/administrasi yang sebenarnya menjadi domain dari Dinas Kehutanan atau Kementerian Kehutanan (lihat kembali Tabel 1).

Dalam beberapa kasus, IUPHHK yang ada di wilayah KPH ada yang sudah mempunyai struktur organisasi yang relatif mantap (untuk mengampu fungsi pengelolaan). Bahkan jika dibandingkan dengan KPH yang baru dibentuk itu sendiri. Idealnya, IUPHHK yang mempunyai struktur yang mantap dan telah melakukan fungsi pengelolaan dengan baik (banyak IUPHHK yang telah mendapatkan pengakuan pengelolaan hutan yang berkelanjutan/ sertifikasi) harusnya dijadikan sebuah unit otonom/mandiri (semacam KPH) yang bukan di bawah KPH baru versi pemerintah, sedangkan fungsi monitoring dan pengawasan terhadap kegiatan fungsi pengelolaan terhadap IUPHHK tersebut menjadi kewenangan pemerintah (Dinas Kehutanan).

Tidak dipungkiri, banyak IUPHHK yang tidak sepenuhnya melakukan fungsi pengelolaan secara holistik. Namun hal ini seyogyanya tidak menafikan bahwa ada IUPHHK yang baik. Dalam kasus IUPHHK yang kinerjanya jauh dari harapan, KPH versi pemerintah dapat dibentuk dan IUPHHK tersebut dapat dijadikan mitra dalam kegiatan pengelolaan. IUPHHK tersebut tetap di bawah kendali dari KPH. Pengendalian oleh KPH didasari oleh salah satu rasionalitas pembentukan KPH yang disebabkan adanya banyak kasus pengelolaan hutan yang bertumpu pada pemegang ijin menjadikan kurangnya mekanisme kontrol dari pemerintah. Oleh karena itu, perencanaan dan implementasi kegiatan IUPHHK semacam ini harus sejalan dengan (mengacu) rencana-rencana yang disusun oleh KPH (yang tentunya akan mengacu perencanaan kehutanan daerah dan nasional).

\section{Hubungan KPH dengan UPT Kementerian Kehutanan}

UPT merupakan lengan Kementerian Kehutanan yang mempunyai tupoksi tertentu. Dalam konteks tata hubungan kerja dengan KPH, UPT dapat menjadi institusi pendukung bagi pelaksanaan pengelolaan hutan, terutama pada masa transisi sebelum KPH menjadi unit pengelolaan yang mandiri. Fasilitasi dan dukungan dari UPT ini bisa mencakup berbagai aspek seperti perencanaan, teknis kehutanan, dan sumberdaya manusia. Misalnya, sebelum KPH benar-benar mandiri, UPT-UPT ini bersama-sama dengan Dinas Kehutanan dapat menyusun rencana jangka panjang pengelolaan hutan. Selain itu, UPT dapat 
memberikan asistensi teknis kegiatan pengelolaan. Sebagai contoh, BPKH dapat mengambil peran dalam kegiatan tata hutan dan pengukuhan kawasan. $\mathrm{KPH}$ mempunyai tantangan yang sangat krusial terkait dengan tata hutan, terutama untuk kawasan produksi yang secara de facto sudah menjadi kawasan open-access. UPT juga dapat mengampu fungsi koordinasi KPH dengan Kementerian Kehutanan. Misalnya, BP2HP dapat menjalankan fungsi koordinasi untuk BAPLAN dan Bina Usaha Kehutanan terkait dengan konteks pemanfaatan hutan dan perijinannya. Untuk kegiatan pengelolaan lain, misalnya rehabilitasi kawasan, BPDAS dapat menjalankan fungsi koordinasi antara KPH dengan Pemerintah Daerah terutama dalam penentuan kawasan rehabilitasi dan pemeliharaan serta pemanfaatan tanaman.

\section{KESIMPULAN DAN REKOMENDASI}

Beberapa hal yang dapat dijadikan pertimbangan dalam penyusunan tata hubungan kelembagaan KPH adalah:

1. KPH dijadikan sebagai UPT Dinas Kehutanan. Namun, KPH harus didorong untuk menjadi sebuah unit pengelolaan yang mandiri kreasi dalam menterjemahkan arahan kebijakan yang ada, dan dalam menetapkan pilihan-pilihan kegiatan didasarkan pada analisis trajektori dan proyeksi pengelolaan sumberdaya hutan berdasarkan kebijakan yang ditelorkan oleh Dinas Kehutanan.

2. IUPHHK yang sudah ada, terutama yang telah melakukan fungsi pengelolaan yang baik dan holistik, harus dijadikan sebagai KPH tersendiri dan tidak lagi dinaungi oleh KPH versi pemerintah. Fungsi pengawasan terhadap IUPHHK ini diampu oleh Dinas Kehutanan, bukan diampu oleh KPH versi pemerintah. IUPHHK yang belum menjalankan fungsi pengelolaan secara holistik dapat dijadikan mitra dalam kegiatan pengelolaan. IUPHHK tersebut tetap di bawah kendali dari KPH yang diawasi oleh Dinas Kehutanan.

UPT Kementerian Kehutanan yang ada di daerah dapat memainkan peran yang sangat strategis dalam masa transisi (transitional phase) KPH menuju unit pengelolaan yang mandiri. UPT-UPT ini diharapkan memberikan fasilitasi dan berbagai dukungan yang mencakup berbagai aspek seperti perencanaan, teknis kehutanan, dan sumberdaya manusia. Untuk selanjutnya, UPT-UPT yang ada akan lebih berperan dalam fungsi koordinasi antara KPH dengan Kementerian Kehutanan.

\section{DAFTAR PUSTAKA}

Brockhaus M, Obidzinski K, Dermawan A, Laumonier Y, \& Lutrell C. 2012. An overview of forest and land allocation policies in Indonesia: Is the current framework sufficient to meet the needs of REDD+? Forest Policy and Economics 18, 30-37.

Departemen Kehutanan 2006. Buku Pintar Bidang Planologi Kehutanan. Jakarta. http://www. dephut.go.id/index.php/news/details/2584.

Diakses 3 November 2015.

Giessen L \& Krott M. 2009. Forestry Joining Integrated Programmes? A question of willingness, ability and opportunities. Allgemeine Forst- und Jagdzeitung 180 (5-6), 94-100.

Giessen L, Krott M, \& Moellmann T. 2014. Increasing representation of states by utilitarian as compared to environmental bureaucracies in international forest and forest-environmental policy negotiations. Forest Policy and Economics 38, 97-104.

Hansen MC, Potapov PV, Moore R, Hancher, Turubanova SA, Tyukavina A, Thau D, Stehman SV, Goetz SJ, Loveland TR, Kommareddy A, Egorov A, Chini L, Justice, CO, \& Townshend JRG. 2013. High-resolution global maps of 21 st-century forest cover change. Science 342, 850-853. 
Hubo C \& Krott M. 2010. Politiksektoren als Determinanten von Umweltkonflikten am Beispiel invasiver gebietsfremder Arten. Dalam : Umwelt-und Technikkonflikte. 219-238.

Hubo C \& Krott M. 2013. Conflict camouflaging in public administration - a case study in nature conservation policy in Lower Saxony. Forest Policy and Economics 33, 63-70

Hurst P. 1990. Rainforest Politics: Ecological Destruction in Southeast Asia. Zed Books, London and New Jersey.

Kartodihardjo H, Nugroho B, \& Putro HR. 2011. Forest Management Unit Development Concept, Legislation and Implementation. Directorate of Area Management and Preparation of Forest Area Utilisation, Directorate General of Forestry Planning, Ministry of Forestry.

Kementrian Kehutanan. 2012. Statistik Kehutanan Indonesia 2011. Jakarta

Kim Y-s, Bae, JS, Fisher LA, Latifah S, Afifi M, Lee SM, \& Kim I-a. 2015. Indonesia's Forest Management Units: Effective intermediaries in REDD + implementation? Forest Policy and Economics 62, 69-77.

Krott M, Bader A, Schusser C, Devkota R, Maryudi A, Giessen L, \& Aurenhammer H. 2014. Actor-centered power: the driving force in decentralized community based forest governance. Forest Policy and Economics 49, 34-42.

Krott M. 1990. Öffentliche Verwaltung im Umweltschutz. Ergebnisse einer behördenorientierten Policy Analyse am Beispiel Waldschutz. W. Braumüller Verlag, Wien.

Krott M. 2005. Forest Policy Analysis (translated by Renee von Paschen). Springer Publications.

Light PC. 1997. The Tides of Reform:Making Government Work 1945-1995. New Haven, CT: Yale University Press.

Marinetto M. 2003. Governing beyond the Centre: A critique of the Anglo-Governance School. Political Studies 51, 592-608

Maryudi A. 2015. The political economy of forest land-use, the timber sector, and forest certification. Dalam : The context of Natural Forest Management and FSC Certification in Indonesia. Romero C. (Eds). Center for International Forestry Research, Bogor

McCarthy J. 2000. The changing regime : Forest property and reformasi in Indonesia. Development and Change 31(1), 91-129
Nagel JH. 1997. Radically reinventing government: Editor's introduction. Journal of Policy Analysis and Management 16(3), 349-356

Niskanen W. 1971. Bureaucracy and Representative Government. Aldine-Atherton, Chicago

North DC. 1990. Institutions, Institutional Change and Economic Performance. Cambridge University Press, Cambridge

Ostrom E. 1999. Self Governance and Forest Resources. Occasional Paper No. 20. Bogor: Center for International Forestry Research

Peters BG \& Pierre J. 2007. Introduction: the role of public administration in governing. Dalam: The Handbook of Public Administration. Ibid (Eds). Sage, London. 394.

Ruhanen L, Scott N, Ritchie B, \& Tkaczynski A. 2010. Governance: a review and synthesis of the literature. Tourism Review 65 (4), 4-16.

Sahide MAK, Maryudi A, Supratman S, \& Giessen L. 2016. Is Indonesia utilising its international partners? The driving forces behind Forest Management Units. Forest Policy and Economics 69,11-20

Sahide MAK, Supratman S, Maryudi A, Kim Y-s, \& Giessen L. 2016. Decentralisation policy as recentralisation strategy: forest management units and community forestry in Indonesia. International Forestry Review 18(1), 78-95

Terry LD. 2005. The thinning of administrative institutions in the hollow state. Administration \& Society 37(4), 426-444.

World Bank. 1990. Indonesia: Sustainable Development of Forests, Land, and Water. The World Bank: Washington, DC. 